\title{
Front Matter: Volume 10439
}

, "Front Matter: Volume 10439," Proc. SPIE 10439, Millimetre Wave and Terahertz Sensors and Technology X, 1043901 (29 November 2017); doi: $10.1117 / 12.2302589$

SPIE. Event: SPIE Security + Defence, 2017, Warsaw, Poland 


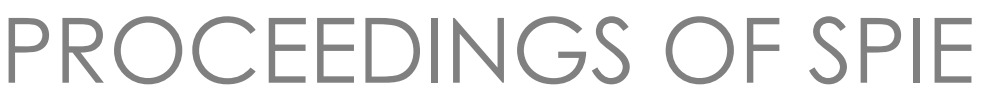

\title{
Millimetre Wave and Terahertz Sensors and Technology $X$
}

\author{
Neil A. Salmon \\ Sherif Sayed Ahmed \\ Editors
}

11 September 2017

Warsaw, Poland

Sponsored by

SPIE

Cooperating Organisations

CENSIS: Innovation Centre for Sensor \& Imaging Systems (United Kingdom)

Polish Technological Platform on Photonics (Poland)

MIRPHAB (France)

Photonics Society of Poland (Poland)

Cranfield University (United Kingdom)

Published by

SPIE 
The papers in this volume were part of the technical conference cited on the cover and title page. Papers were selected and subject to review by the editors and conference program committee. Some conference presentations may not be available for publication. Additional papers and presentation recordings may be available online in the SPIE Digital Library at SPIEDigitalLibrary.org.

The papers reflect the work and thoughts of the authors and are published herein as submitted. The publisher is not responsible for the validity of the information or for any outcomes resulting from reliance thereon.

Please use the following format to cite material from these proceedings:

Author(s), "Title of Paper," in Millimetre Wave and Terahertz Sensors and Technology X, edited by Neil A. Salmon, Sherif Sayed Ahmed, Proceedings of SPIE Vol. 10439 (SPIE, Bellingham, WA, 2017) Seven-digit Article CID Number.

ISSN: 0277-786X

ISSN: 1996-756X (electronic)

ISBN: 9781510613423

ISBN: 9781510613430 (electronic)

Published by

SPIE

P.O. Box 10, Bellingham, Washington 98227-0010 USA

Telephone +1 3606763290 (Pacific Time) · Fax +1 3606471445

SPIE.org

Copyright (C) 2017, Society of Photo-Optical Instrumentation Engineers.

Copying of material in this book for internal or personal use, or for the internal or personal use of specific clients, beyond the fair use provisions granted by the U.S. Copyright Law is authorized by SPIE subject to payment of copying fees. The Transactional Reporting Service base fee for this volume is $\$ 18.00$ per article (or portion thereof), which should be paid directly to the Copyright Clearance Center (CCC), 222 Rosewood Drive, Danvers, MA 01923. Payment may also be made electronically through CCC Online at copyright.com. Other copying for republication, resale, advertising or promotion, or any form of systematic or multiple reproduction of any material in this book is prohibited except with permission in writing from the publisher. The CCC fee code is 0277$786 \mathrm{X} / 17 / \$ 18.00$.

Printed in the United States of America.

Publication of record for individual papers is online in the SPIE Digital Library.

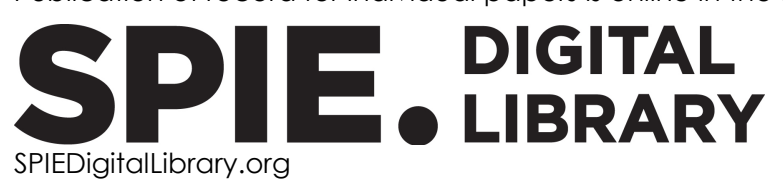

Paper Numbering: Proceedings of SPIE follow an e-First publication model. A unique citation identifier (CID) number is assigned to each article at the time of publication. Utilization of CIDs allows articles to be fully citable as soon as they are published online, and connects the same identifier to all online and print versions of the publication. SPIE uses a seven-digit CID article numbering system structured as follows:

- The first five digits correspond to the SPIE volume number.

- The last two digits indicate publication order within the volume using a Base 36 numbering system employing both numerals and letters. These two-number sets start with 00, 01, 02, 03, $04,05,06,07,08,09,0 A, 0 B \ldots$. 0Z, followed by 10-1Z, 20-2Z, etc. The CID Number appears on each page of the manuscript. 


\title{
Contents
}

\author{
$\checkmark$ Author \\ vii Conference Committee
}

\section{SESSION 1 PHENOMENOLOGY AND SIGNATURES}

1043902 Gas spectroscopy system with transmitters and receivers in SiGe BiCMOS for 225-273 GHz [10439-1]

1043903 Investigation of radiant millimeter wave/terahertz radiation from low-infrared signature targets [10439-2]

1043904 Signatures of human skin in the millimetre wave band (80-100) GHz (Best Student Paper Award) [10439-15]

\section{SESSION 2 NOVEL SYSTEMS}

1043905 Extended sources near-field processing of experimental aperture synthesis data and application of the Gerchberg method for enhancing radiometric three-dimensional millimetre-wave images in security screening portals [10439-5]

1043906 Full polarimetric millimetre wave radar for stand-off security screening [10439-6]

\section{SESSION 3 DEVICES}

1043907 Detection of terahertz radiation using submicron field effect transistors and their use for inspection applications [10439-7]

10439 OA Synthesis of structures of electric small-sized radiators using impedance matching materials for millimeter waves [10439-17]

\section{SESSION 4 IMAGE PROCESSING}

10439 OB Super-resolution image reconstruction applied to an active millimeter wave imaging system based on compressive sensing [10439-9]

10439 OC About efficiency of correlation function using with Fourier transform for the passive THz image quality enhancement [10439-10]

10439 OD Review of terahertz image enhancement techniques [10439-11] 
10439 OF An equivalent method of mixed dielectric constant in passive microwave/millimeter radiometric measurement [10439-13] 


\title{
Authors
}

Numbers in the index correspond to the last two digits of the seven-digit citation identifier (CID) article numbering system used in Proceedings of SPIE. The first five digits reflect the volume number. Base 36 numbering is employed for the last two digits and indicates the order of articles within the volume. Numbers start with 00, 01, 02, 03, 04, 05, 06, 07, 08, 09, 0A, OB...0Z, followed by 10-1Z, 20-2Z, etc.

\author{
Alkuş, Ümit, 03, OB \\ Altan, Hakan, 03, OB \\ Aytaç, B., 03 \\ Belevtsev, Andrey M., OA \\ Blackhurst, Eddie, 06 \\ Borngräber, Johannes, 02 \\ Çankaya, illyas, OB \\ Cheng, Yayun, OF \\ Delgado Notario, J. A., 07 \\ Diez, E., 07 \\ Drize, Artemiy D., OA \\ Epaneshnikova, Irina K., OA \\ Fobelets, K., 07 \\ Garbat, Piotr, OD \\ Godin, Andrey S., OA \\ Gui, Liangqi, OF \\ $\mathrm{Hu}, \mathrm{Fei}, \mathrm{OF}$ \\ Hübers, Heinz-Wilhelm, 02 \\ Javadi, E., 07 \\ Kissinger, Dietmar, 02 \\ Klimov, Konstantin N., OA \\ Kosciug, Bartosz, OD \\ Kovalev, Valentine Yu., OC \\ Loginova, Maria M., OC \\ Meziani, Y. M., 07 \\ Owda, Amani Y., 04 \\ Peng, Xiaohui, OF \\ Rezgui, Nacer-Ddine, 04 \\ Rothbart, Nick, 02 \\ Şahin, Asaf Behzat, 03, OB \\ Salmon, Neil A., 04, 05, 06 \\ Schmalz, Klaus, 02 \\ Şengün Ermeydan, Esra, OB \\ Sivaslıgil, M., 03 \\ Southgate, Matthew, 06 \\ Su, Jinlong, OF \\ Tian, Yan, OF \\ Trofimov, Vladislav $\vee ., O C$ \\ Trofimov, Vyacheslav A., OC \\ Velázquez, J. E., 07 \\ Yilmaz, Selahattin Berk, 02
}


Proc. of SPIE Vol. 10439 1043901-6

Downloaded From: https://www.spiedigitallibrary.org/conference-proceedings-of-spie on 25 Apr 2023 Terms of Use: https://www.spiedigitallibrary.org/terms-of-use 


\title{
Conference Committee
}

\author{
Symposium Chair
}

Ric Schleijpen, TNO Defence, Security and Safety (Netherlands)

Symposium Co-Chairs

Karin Stein, Fraunhofer Institute of Optronics System Technologies and Image Exploitation IOSB (Germany)

Jan K. Jabczyński, Military University of Technology (Poland)

Conference Chairs

Neil A. Salmon, MMW Sensors Ltd. (United Kingdom)

Sherif Sayed Ahmed, Rohde \& Schwarz GmbH \& Company KG (Germany)

Conference Program Committee

Amir Abramovich, Ariel University (Israel)

Hakan Altan, Middle East Technical University (Turkey)

Nicholas J. Bowring, Manchester Metropolitan University (United Kingdom)

Gerald S. Buller, Heriot-Watt University (United Kingdom)

Helge Bürsing, Fraunhofer-Institut für Optronik, Systemtechnik und Bildauswertung (Germany)

Felicity Carlysle-Davies, Forensic Science SIG KTN (United Kingdom)

Stephan Dill, Deutsches Zentrum für Luft- und Raumfahrt e.V. (Germany)

Charmaine Cisneros Franck, NASA Langley Research Center (United States)

Marcin Kowalski, Military University of Technology (Poland)

Wojciech Knap, Université Montpellier 2 (France)

Robert A. Lamb, Selex Galileo Ltd. (United Kingdom)

Steven R. Murrill, U.S. Army Research Laboratory (United States)

Markus Peichl, Deutsches Zentrum für Luft- und Raumfahrt e.V. (Germany)

Douglas T. Petkie, Wright State University (United States)

Christopher A. Schuetz, Phase Sensitive Innovations, Inc. (United States)

Vyacheslav A. Trofimov, Lomonosov Moscow State University (Russian Federation)

Vincent P. Wallace, The University of Western Australia (Australia) 
Session Chairs

1 Phenomenology and Signatures

Neil A. Salmon, MMW Sensors Ltd. (United Kingdom)

Marcin Kowalski, Wojskowa Akademia Techniczna im. Jaroslawa Dabrowskiego (Poland)

Charmaine Cisneros Franck, NASA Langley Research Center (United States)

2 Novel Systems

Wojciech Knap, Université Montpellier (France)

Frank Gumbmann, Rohde \& Schwarz GmbH \& Company KG (Germany)

Vyacheslav A. Trofimov, M.V. Lomonosov Moscow State University (Russian Federation)

3 Devices

Charmaine Cisneros Franck, NASA Langley Research Center (United States)

Marcin Kowalski, Wojskowa Akademia Techniczna im. Jaroslawa Dabrowskiego (Poland)

$4 \quad$ Image Processing

Wojciech Knap, Université Montpellier (France)

Frank Gumbmann, Rohde \& Schwarz GmbH \& Company KG (Germany)

Neil A. Salmon, MMW Sensors Ltd. (United Kingdom) 